ADLFI. Archéologie de la France -

\title{
Rembercourt-Sommaisne
}

\section{Stéphanie Jacquemot}

Édition électronique
URL : http://journals.openedition.org/adlfi/9096

ISSN : 2114-0502

Éditeur

Ministère de la culture

\section{Référence électronique}

Stéphanie Jacquemot, «Rembercourt-Sommaisne », ADLFI. Archéologie de la France - Informations [En ligne], Lorraine, mis en ligne le 01 mars 2001, consulté le 01 mai 2019. URL : http:// journals.openedition.org/adlfi/9096

Ce document a été généré automatiquement le 1 mai 2019.

(c) Ministère de la Culture et de la Communication, CNRS 


\title{
Rembercourt-Sommaisne
}

\author{
Stéphanie Jacquemot
}

Identifiant de l'opération archéologique : F1355200100032

Date de l'opération : 2001 (EV)

1 La découverte fortuite d'un trésors monétaire gallo-romain au XIX ${ }^{\mathrm{e}} \mathrm{s}$. sur ce terrain a motivé la réalisation d'un diagnostic archéologique préalable à la construction d'un bâtiment agricole, d'une surface au sol de $1030 \mathrm{~m}^{2}$. Aucun indice archéologique n'a été mis au jour.

\section{INDEX}

Index géographique : Lorraine, Meuse (55), Rembercourt-Sommaisne

Thèmes : monnaie

operation Fouille d'évaluation (EV)

\section{AUTEURS}

STÉPHANIE JACQUEMOT

SDA 